Jurnal Pemberdayaan Masyarakat Madani (JPMM) E-ISSN: 2580-4332

Vol 2 No 1 (Juli) 2018

DOI: https://10.21009/JPMM.002.1.10

\title{
Workshop Teknik Menganalisis Butir Soal dalam Meningkatkan Kompetensi Guru di SMK Cileungsi Bogor
}

\author{
Ati Sumiati \\ Universitas Negeri Jakarta, Atis.june@gmail.com \\ Umi Widiastuti \\ Universitas Negeri Jakarta, Umiwidyastuti.feunj@gmail.com \\ Usep Suhud \\ Universitas Negeri Jakarta, Usuhud@unj.ac.id
}

\begin{abstract}
Activities of devotion to the public was all intended to help the level of a unit of education and in the teacher raising the standard of living in competence is the need of evaluation hands on learning uses the technique that analysis an easy one and pleasing.Universitas Negeri Jakarta, as educators who took on task of Tri Dharma Perguruan Tinggi. One of which is the third Darma, devotion to the public. The Implemented of it, educators and Faculty of Economics' family member UNJ have done education for public through development of competence to Vocational High School's teacher.Workshop technique analyze details of problem within increase competence of vocational teacher in evaluation learning accordance 2013 curriculum in VHS Cileungsi, Bogor, be held on Saturday, May $13^{\text {th }} 2197$ in multi function room VHS Amal Mulia Kab. Bogor that attend by all of teachers.The workshop helps teachers in evaluation of test that used. The training is expected that could add more teacher's knowledges about technique analyze details of problem either qualitative or quantitative and could design question accordance with the achievement of competence effectively. In future, be expected will be model of technique analyze details of problem for teacher either manual or electronic
\end{abstract}

Keywords:Technique analyze details of problem

Available at

http://journal.unj.ac.id/unj/index.php/jpm 


\section{PENDAHULUAN}

\section{Analisis Situasi}

Kegiatan menganalisis

butir soal merupakan suatu kegiatan yang harus dilakukan guru untuk meningkatkan mutu soal yang telah ditulis. Kegiatan ini merupakan proses pengumpulan, peringkasan, dan penggunaan informasi dari jawaban siswa untuk membuat keputusan tentang setiap penilaian (Nitko, 1996: 308). Tujuan penelaahan adalah untuk mengkaji dan menelaah setiap butir soal agar diperoleh soal yang bermutu sebelum soal digunakan. Di samping itu, tujuan analisis butir soal juga untuk membantu meningkatkan tes melalui revisi atau membuang soal yang tidak efektif, serta untuk mengetahui informasi diagnostik pada siswa apakah mereka sudah/belum memahami materi yang telah diajarkan (Aiken, 1994: 63). Soal yang bermutu adalah soal yang dapat memberikan informasi setepattepatnya sesuai dengan tujuannya di antaranya dapat menentukan peserta didik mana yang sudah atau belum menguasai materi yang Available at http://journal.unj.ac.id/unj/index.php/jpm diajarkan guru.

Fenomena yang terjadi adalah tidak semuanya guru memiliki kompetensi dalam menganalisis butir soal yang telah di ujikan kepada siswa. Hal ini pun dikarenakan tidak semua sekolah mewajibkan kepada gurunya untuk menganalisis butir soal, sehingga guru merasa bahwa kompetensi tersebut tidak perlu dimiliki. Padahal dalam melaksanakan analisis butir soal, guru dapat menganalisis secara kualitatif dan kuantitatif. Analisis kualitatif mencakup pertimbangan validitas isi dan konstruk, sedangkananalisis kuantitatif mencakup pengukuran kesulitan butir soal dan diskriminasi soal yang termasuk validitas soal dan reliabilitasnya.

\section{Perumusan Masalah}

Dari latar belakang yang telah dikemukakan tedapat masalah yaitu : Apakah setiap satuan pendidikan dan guru memiliki kompetensi dalam menganalisis butir soal (item) guna meningkatkan mutu soal yang baik sebagai alat evaluasi dalam pembelajaran atau kegiatan belajar mengajar berdasarkan 
kurikulum 2013?

\section{Tujuan dan Manfaat}

Tujuan pengabdian kepada masyarakat ini adalah untuk mengidentifikasi kesulitankesulitan apa yang dihadapi oleh guru dalam menganalisis butir soal serta memberikan pengetahuan mengenai bagaimana teknik analisis butir soal yang dapat diterapkan guru disekolah.

\section{KAJIAN TEORITIK}

Pada prinsipnya analisis butir soal secara kualitatif dilaksanakan berdasarkan kaidah penulisan soal (tes tertulis, perbuatan, dan sikap). Penelaahan ini biasanya dilakukan sebelum soal digunakan/diujikan.

Teknik analisis butir soal secara kualitatif dalam kaitan dengan isi dan bentuknya, dan kuantitatif dalam kaitan dengan ciriciri statistiknya (Anastasi dan Urbina, 1997: 172) atau prosedur peningkatan secara judgment dan prosedur peningkatan secara empirik (Popham, 1995: 195). Aspek yang diperhatikan di dalam penelaahan secara kualitatif ini adalah setiap soal ditelaah dari segi Available at http://journal.unj.ac.id/unj/index.php/jpm materi, konstruksi, bahasa/budaya, dan kunci jawaban/pedoman penskorannya. Dalam melakukan penelaahan setiap butir soal, penelaah perlu mempersiapkan bahan-bahan penunjang seperti: (1) kisi-kisi tes, (2) kurikulum yang digunakan, (3) buku sumber, dan (4) kamus bahasa Indonesia.

Ada beberapa teknik yang dapat digunakan untuk menganalisis butir soal secara kualitatif, diantaranya adalah teknik moderator dan teknik panel.

Teknik moderator merupakan teknik berdiskusi yang di dalamnya terdapat satu orang sebagai penengah. Berdasarkan teknik ini, setiap butir soal didiskusikan secara bersamasama dengan beberapa ahli seperti guru yang mengajarkan materi, ahli materi, penyusun/pengembang kurikulum, ahli penilaian, ahli bahasa, berlatar belakang psikologi. Teknik ini sangat baik karena setiap butir soal dilihat secara bersamasama berdasarkan kaidah penulisannya.

Teknik panel merupakan suatu teknik menelaah butir soal yang setiap butir soalnya ditelaah 
berdasarkan kaidah penulisan butir soal, yaitu ditelaah dari segi materi, konstruksi, bahasa/budaya, kebenaran kunci jawaban/pedoman penskorannya yang dilakukan oleh beberapa penelaah

\section{MATERI DAN METODE}

\section{Kerangka Pemecahan Masalah}

Rendahnya pengetahuan dan kemampuan guru SMK dalam menganalisis butir soal di Cileungsi Bogor, maka diperlukan workshop bagi guru-guru dlam menganalisis butir soal demi untuk meningkatkan kompetensi mereka dalam evaluasi pembelajaran.

\section{Realisasi Pemecahan Masalah}

\section{Guru diberikan pengetahuan dasar mengenai konsep analisis butir soal}

Adapun materi yang disampaikan adalah terkait analisis butir soal baik secara kualitatif maupun kuantitatif, yaitu sebagai berikut:

Dalam menganalisis butir soal secara kualitatif, penggunaan format penelaahan soal akan sangat membantu dan mempermudah prosedur pelaksanaannya. Format Available at http://journal.unj.ac.id/unj/index.php/jpm penelaahan soal digunakan sebagai dasar untuk menganalisis setiap butir soal. Format penelaahan soal yang dimaksud adalah format penelaahan butir soal: uraian, pilihan ganda, tes perbuatan dan instrumen non-tes.

Agar penelaah dapat dengan mudah menggunakan format penelaahan soal, maka para penelaah perlu memperhatikan petunjuk pengisian formatnya. Petunjuknya adalah seperti berikut ini.

1. Analisislah setiap butir soal berdasarkan semua kriteria yang tertera di dalam format!

2. Berilah tanda cek (V) pada kolom "Ya" bila soal yang ditelaah sudah sesuai dengan kriteria!

3. Berilah tanda cek (V) pada kolom "Tidak" bila soal yang ditelaah tidak sesuai dengan kriteria, kemudian tuliskan alasan pada ruang catatan atau pada teks soal dan perbaikannya. 
FORMAT PENELAAHAN BUTIR SOAL BENTUK

URAIAN

Mata Pelajaran

Kelas/semester

Penelaah

TABEL.1 Format Penelahaan Butir Soal BentukUraian

\begin{tabular}{|c|c|c|c|c|c|c|c|c|c|c|c|}
\hline \multirow{2}{*}{ No. } & \multirow{2}{*}{ Aspek yang ditelaah } & \multicolumn{10}{|c|}{ lvomor soal } \\
\hline & & 1 & 2 & 3 & 4 & 5 & 6 & 7 & 8 & 9 & ... \\
\hline A. & Materi & & & & & & & & & & \\
\hline 1 & Soal sesuai dengan indikator & & & & & & & & & & \\
\hline & (menuntut tes tertulis untuk bentuk & & & & & & & & & & \\
\hline 2 & Uraian) & & & & & & & & & & \\
\hline & Batasanpertanyaan dan jawaban & & & & & & & & & & \\
\hline 3 & yang diharapkansudahsesuai & & & & & & & & & & \\
\hline & Materi yang & & & & & & & & & & \\
\hline & ditanyakansesuaidengankompetensi & & & & & & & & & & \\
\hline & (urgensi, relevasi, kontinyuitas, & & & & & & & & & & \\
\hline 4 & keterpakaiansehari-haritinggi) & & & & & & & & & & \\
\hline & Isi materi yang ditanyakan sesuai & & & & & & & & & & \\
\hline & dengan jenjang jenis sekolah atau & & & & & & & & & & \\
\hline & tingkat kelas & & & & & & & & & & \\
\hline B & Konstruksi & & & & & & & & & & \\
\hline 5 & Menggunakan kata tanya atau & & & & & & & & & & \\
\hline & perintah yang menuntut jawaban & & & & & & & & & & \\
\hline & uraian & & & & & & & & & & \\
\hline 6 & Ada petunjuk yang jelas tentang & & & & & & & & & & \\
\hline & cara mengerjakan soal & & & & & & & & & & \\
\hline 7 & Ada pedoman penskorannya & & & & & & & & & & \\
\hline 8 & Tabel, gambar, grafik, peta, atau & & & & & & & & & & \\
\hline
\end{tabular}




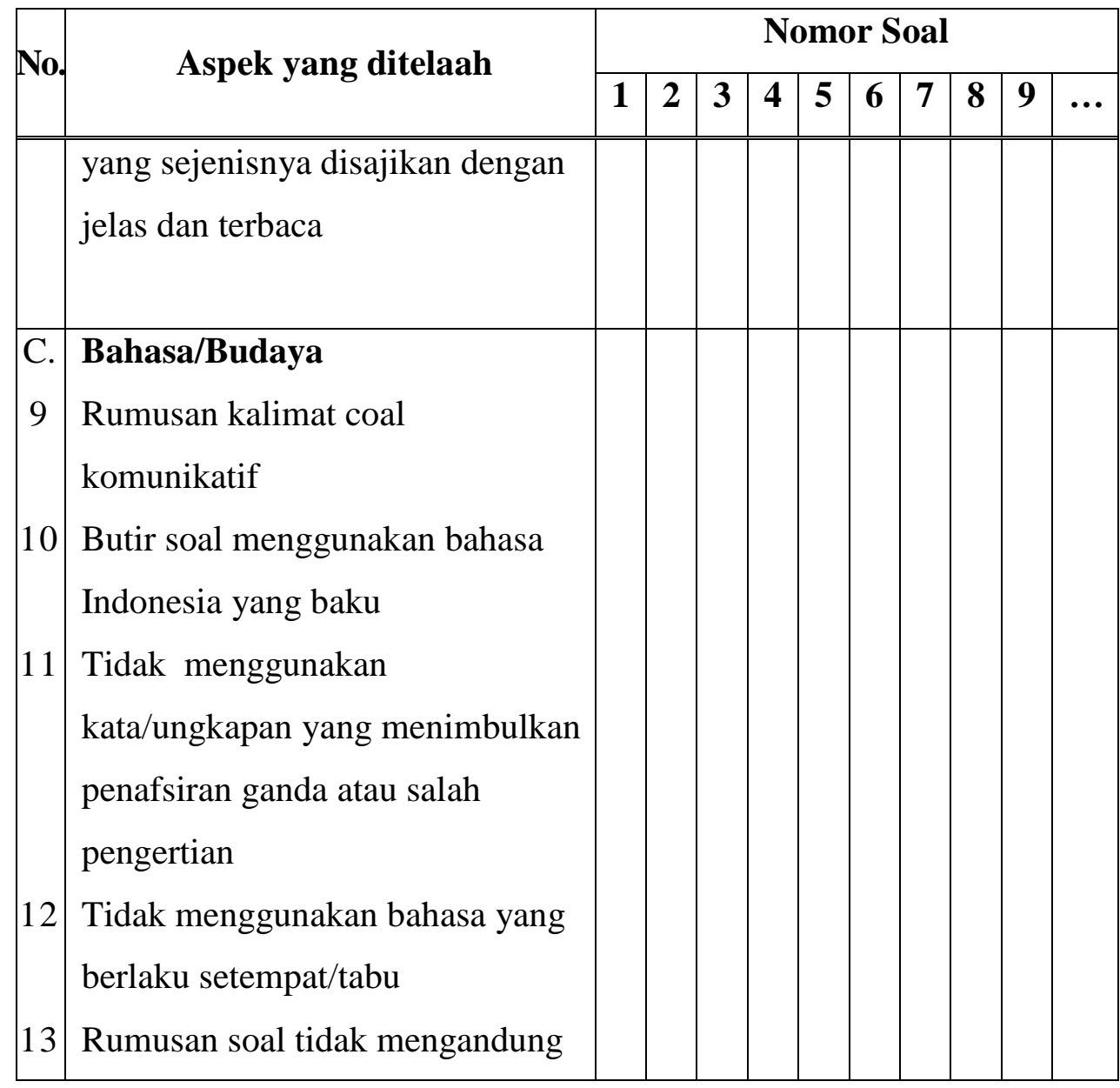

Keterangan: Berilah tanda (V) bila tidak sesuai dengan aspek yang ditelaah!

FORMAT PENELAAHAN SOAL BENTUK PILIHAN GANDA

Mata Pelajaran :

Kelas/semester :

Penelaah

TABEL.2 Format Penelahaan Soal Bentuk Pilihan Ganda

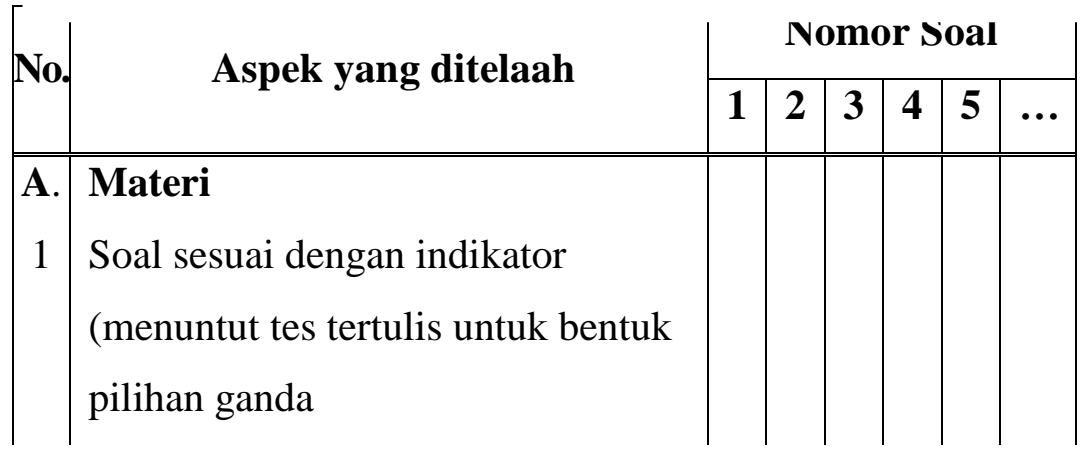




\begin{tabular}{|c|c|c|c|c|c|c|c|}
\hline \multirow{2}{*}{ No. } & \multirow{2}{*}{ Aspek yang ditelaah } & \multicolumn{6}{|c|}{ Nomor Soal } \\
\hline & & 1 & 2 & 3 & 4 & 5 & ... \\
\hline 2. & $\begin{array}{l}\text { Materi yang ditanyakan sesuai } \\
\text { dengan kompetensi (urgensi, } \\
\text { relevasi, kontinyuitas, keterpakaian } \\
\text { sehari-hari tinggi) }\end{array}$ & & & & & & \\
\hline 3. & Pilihan jawaban homogen dan logis & & & & & & \\
\hline 4. & Hanya ada satu kunci jawaban & & & & & & \\
\hline B. & Konstruksi & & & & & & \\
\hline 5. & $\begin{array}{l}\text { Pokok soal dirumuskan dengan } \\
\text { singkat, jelas, dan tegas }\end{array}$ & & & & & & \\
\hline 6. & $\begin{array}{l}\text { Rumusan pokok soal dan pilihan } \\
\text { jawaban merupakan pernyataan } \\
\text { yang diperlukan saja }\end{array}$ & & & & & & \\
\hline 7. & $\begin{array}{l}\text { Pokok soal tidak memberi petunjuk } \\
\text { kunci jawaban }\end{array}$ & & & & & & \\
\hline 8 & $\begin{array}{l}\text { Pokok soal bebas dan pernyataan } \\
\text { yang bersifat negatif ganda }\end{array}$ & & & & & & \\
\hline 9. & $\begin{array}{l}\text { Pilihan jawaban homogen dan logis } \\
\text { ditinjau dari segi materi }\end{array}$ & & & & & & \\
\hline 10. & $\begin{array}{l}\text { Gambar, grafik, tabel, diagram, } \\
\text { atau sejenisnya jelas dan berfungsi }\end{array}$ & & & & & & \\
\hline 11. & $\begin{array}{l}\text { Panjang pilihan jawaban relatif } \\
\text { sama }\end{array}$ & & & & & & \\
\hline 12. & $\begin{array}{l}\text { Pilihan jawaban tidak } \\
\text { menggunakan pernyataan "semua } \\
\text { jawaban di atas salah/benar" dan } \\
\text { sejenisnya }\end{array}$ & & & & & & \\
\hline 13. & $\begin{array}{l}\text { Pilihan jawaban yang berbentuk } \\
\text { angka/waktu disusun berdasarkan }\end{array}$ & & & & & & \\
\hline
\end{tabular}




\begin{tabular}{|c|c|c|c|c|c|c|c|}
\hline \multirow{2}{*}{ No. } & \multirow{2}{*}{ Aspek yang ditelaah } & \multicolumn{6}{|c|}{ Nomor Soal } \\
\hline & & 1 & 2 & 3 & 4 & 5 & ... \\
\hline 14. & $\begin{array}{l}\text { urutan besar kecilnya angka atau } \\
\text { kronologisnya } \\
\text { Butir soal tidak bergantung pada } \\
\text { jawaban soal sebelumnya }\end{array}$ & & & & & & \\
\hline C. & Bahasa/Budaya & & & & & & \\
\hline 15. & $\begin{array}{l}\text { Menggunakan bahasa yang sesuai } \\
\text { dengan kaidah bahasa Indonesia }\end{array}$ & & & & & & \\
\hline 16. & $\begin{array}{l}\text { Menggunakan bahasa yang } \\
\text { komunikatif }\end{array}$ & & & & & & \\
\hline 17. & $\begin{array}{l}\text { Tidak menggunakan bahasa yang } \\
\text { berlaku setempat/tabu }\end{array}$ & & & & & & \\
\hline 18. & $\begin{array}{l}\text { Pilihan jawaban tidak mengulang } \\
\text { kata/kelompok katayang sama, kecuali } \\
\text { merupakan satu kesatuan pengertian }\end{array}$ & & & & & & \\
\hline
\end{tabular}

Keterangan: Berilahtanda (V) bila tidak sesuai dengan aspek yang ditelaah!

\section{FORMAT PENELAAHAN SOAL TES PERBUATAN}

Mata Pelajaran :

Kelas/semester :

Penelaah

Tabel.3.Format Penelahaan Soal Tes Perbuatan

\begin{tabular}{|c|c|c|c|c|c|}
\hline \multirow[t]{2}{*}{ No. } & \multirow[t]{2}{*}{ Aspek yang ditelaah } & \multicolumn{4}{|c|}{$\begin{array}{c}\text { Nomor } \\
\text { Soal }\end{array}$} \\
\hline & & 1 & 2 & 3 & $\ldots$ \\
\hline $\begin{array}{l}\text { A. } \\
1 .\end{array}$ & $\begin{array}{l}\text { Materi } \\
\text { Soal sudah sesuai dengan indikator } \\
\text { (menuntut tes perbuatan: kinerja, hasil }\end{array}$ & & & & \\
\hline
\end{tabular}




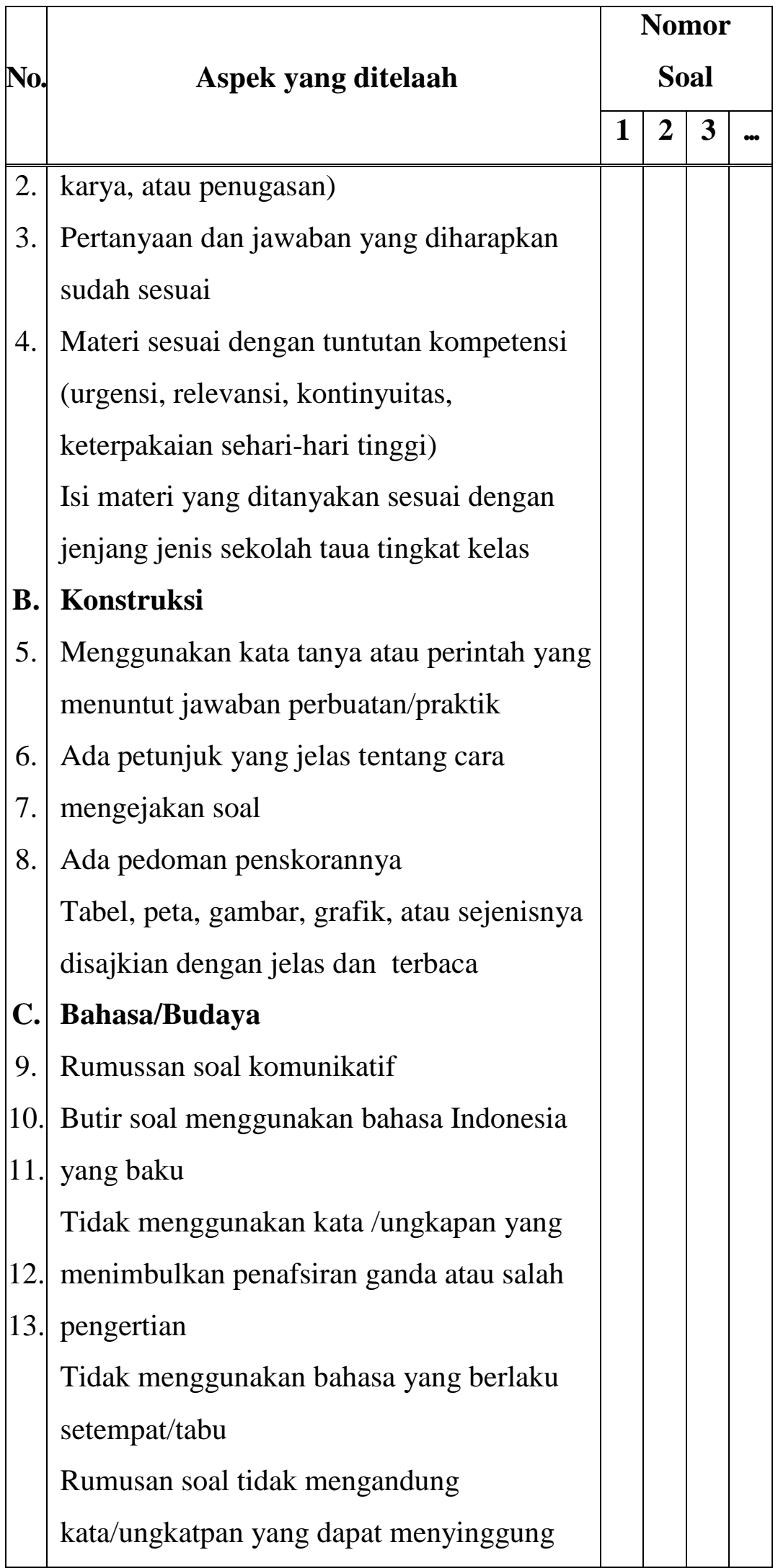




\begin{tabular}{|l|l|c|c|c|c|}
\hline \multirow{2}{*}{ No. Aspek yang ditelaah } & \multicolumn{4}{|c|}{ Nomor } \\
\cline { 3 - 6 } & & \multicolumn{4}{|c|}{ Soal } \\
\cline { 3 - 6 } & & $\mathbf{1}$ & $\mathbf{2}$ & $\mathbf{3}$ & $\ldots$ \\
\hline \hline & perasaan siswa & & & & \\
\hline
\end{tabular}

Keterangan: Berilah tanda (V) bila tidak sesuai dengan aspek yang ditelaah!

\section{FORMAT PENELAAHAN SOAL NON-TES}

Nama Tes

Kelas/semester :

Penelaah

Tabel.4.Format Penelaahan soal Non-Tes

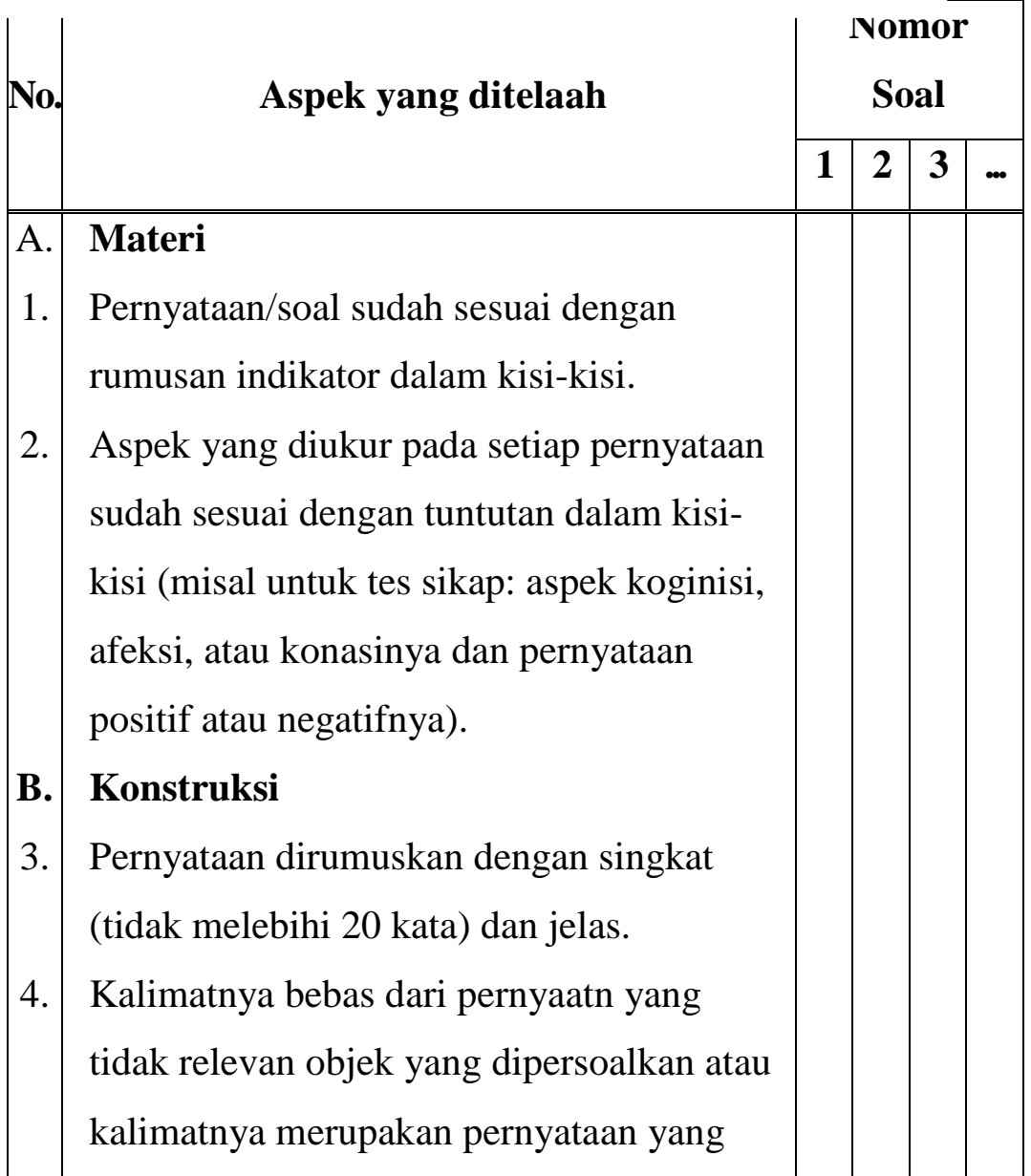




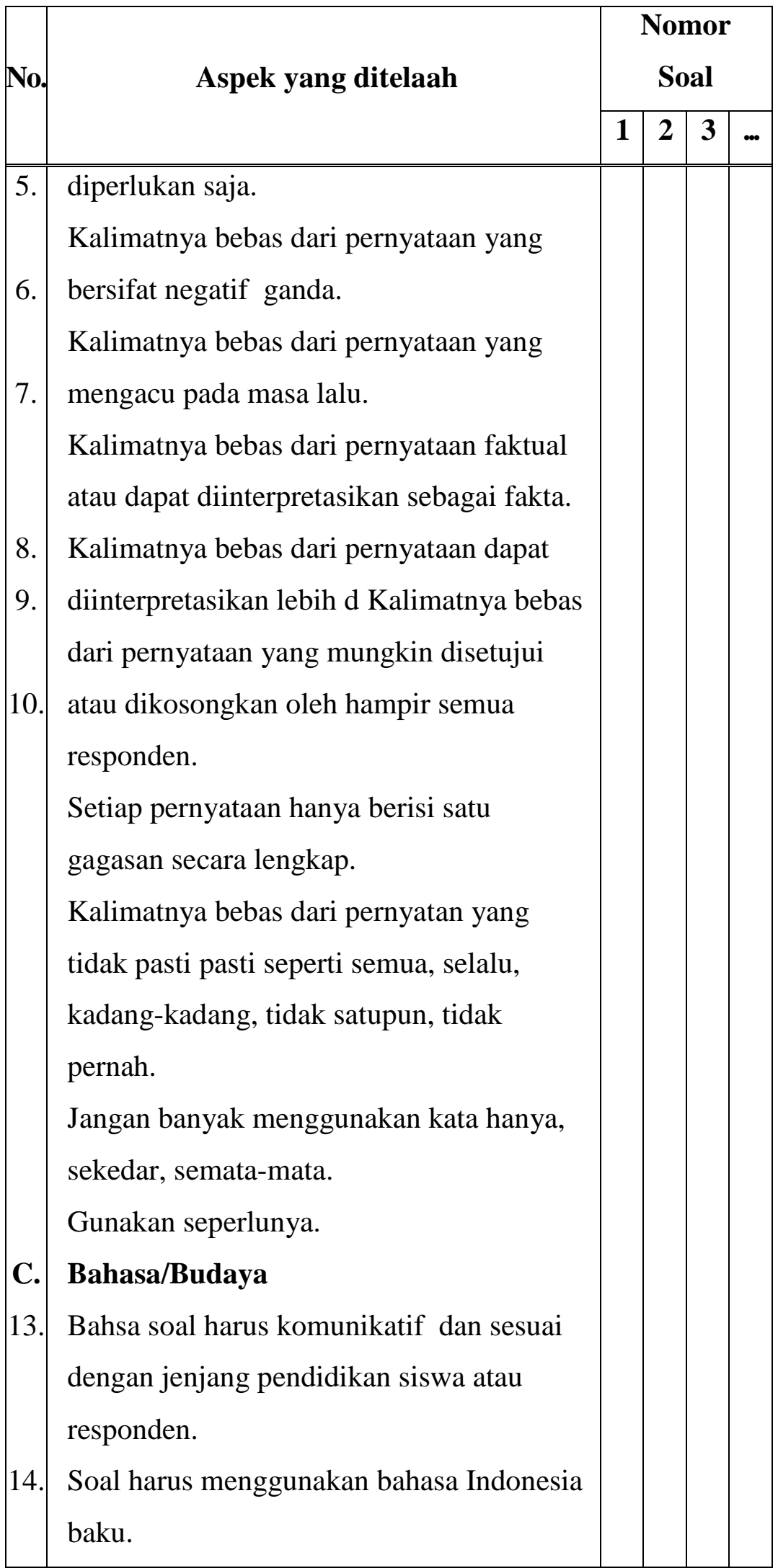




\begin{tabular}{|c|l|c|c|c|c|}
\hline \multirow{2}{*}{ No. } & \multicolumn{1}{|c|}{ Aspek yang ditelaah } & \multicolumn{4}{|c|}{ Nomor } \\
\cline { 3 - 6 } & \multicolumn{4}{|c|}{ Soal } \\
\cline { 3 - 6 } & $\begin{array}{l}\text { Soal tidak menggunakan bahasa yang } \\
\text { berlaku setempat/tabu. }\end{array}$ & & & & \\
\hline
\end{tabular}

Keterangan: Berilah tanda (V) bila tidak sesuai dengan aspek yang ditelaah!

Penelaahan soal secara Tingkat kesukaran soal adalah kuantitatif maksudnya adalah peluang untuk menjawab benar suatu penelaahan butir soal didasarkan pada data empirik dari butir soal yang bersangkutan. Data empirik ini diperoleh dari soal yang telah diujikan.

Analisis butir soal yang relatif mudah dan sering di implementasikan di setiap sekolah adalah Analisis butir soal secara klasik. Analaisis soal secara klasik adalah proses penelaahan butir soal melalui informasi dari jawaban peserta didik guna meningkatkan soal pada tingkat kemampuan tertentu yang biasanya dinyatakan dalam bentuk indeks.

Perhitungan indeks tingkat kesukaran ini di lakukan untuk setiap nomor soal. Pada prinsipnya, skor rata-rata yang diperoleh peserta didik pada butir soal yang bersangkutan dinamakan tingkat kesukaran butir soal itu. Rumus ini dipergunakan untuk soal obyektif. Rumusnya adalah seperti berikut ini (Nitko, 1996: 310). mutu butir soal yang bersangkutan dengan menggunakan teori tes klasik.

Tingkat Kesukaran $(\mathrm{TK})=\frac{\text { Jumlah siswa yang menjawab benar butir soal }}{\text { Jumlah siswa yang mengikuti tes }}$ 
Fungsi tingkat kesukaran kesukaran tinggi/sukar, dan untuk butir soal biasanya dikaitkan keperluan diagnostik biasanya dengan tujuan tes. Misalnya untuk digunakan butir soal yang memiliki keperluan ujian semester tingkat kesukaran rendah/mudah. digunakan butir soal yang Untuk mengetahui tingkat memiliki tingkat kesukaran sedang, kesukaran soal bentuk uraian untuk keperluan seleksi digunakan digunakan rumus berikut ini. butir soal yang memiliki tingkat

$$
\text { Mean }=\frac{\text { Jumah skor.siswa peserta tes pada suatu soal }}{\text { Jumlah peserta didik yang mengikuti tes }}
$$

$$
\text { Tingkat Kesuli tan }=\frac{\text { Mean }}{\text { Skor maksimum yang ditetapkan }}
$$

Hasil perhitungan dengan menggunakan rumus di atas menggambarkan tingkat kesukaran soal itu. Klasifikasi tingkat kesukaran soal dapat dicontohkan seperti berikut ini.

- 0,00 - 0,30 soal tergolong sukar

- 0,31 - 0,70 soal tergolong sedang

- 0,71 - 1,00 soal tergolong mudah

Daya pembeda soal adalah kemampuan suatu butir soal dapat membedakan antara warga belajar/siswa yang telah menguasai materi yang ditanyakan dan warga belajar/siswa yang tidak/kurang/belum menguasai materi yang ditanyakan.

Available at http://journal.unj.ac.id/unj/index.php/jpm
Pola jawaban soal adalah distribusi test dalam hal menentukan pilihan jawaban pada soal bentuk pilihan ganda. Pola jawaban soal diperoleh dengan menghitung banyaknya test yang memilih pilihan jawaban a, b, c, dan d. Dalam istilah evaluasi disebut omit, disingkat $\mathrm{O}$. dari pola jawaban soal dapat ditentukan apakah pengecoh (distractor) berfungsi sebagai pengecoh dengan baik atau tidak. Pengecoh yang tidak dipilih sama sekali oleh testee berarti bahwa pengecoh itu jelek, terlalu menyolok menyesatkan. 
Dengan melihat pola jawaban soal, dapat diketahui :

1. Taraf kesukaran soal

2. Daya pembeda soal

3. Baik dan tidaknya distraktor Sesuatu diktraktor dapat diperlakukan dengan 3 cara :

a. Diterima, karena sudah baik

b. Ditolak, karena tidak baik

Ditulis kembali, karena kurang baik

\section{Hubungan Taraf Kesukaran dan Daya Beda Suatu Item}

Suatu item yang sukar sekali (TK rendah sekali) atau mudah sekali (TK tinggi sekali) biasanya kemampuan membedakannya kecil (TK rendah). Hal siswa ini terjadi karena suatu item yang sukar sekali hanya dapat dikerjakan oleh siswa kelompok atas. Suatu item yang mudah sekali berarti sebagian terbesar siswa termasuk kelompok bawah dapat memberikan jawaban benar.

Item yang demikian hampir tidak dapat membedakan jawaban benar dari siswa-siswa yang tergolong kelompok atas dan bawah. Sedangkan item-item yang mudah atau sukar biasanya masih cukup

Available at http://journal.unj.ac.id/unj/index.php/jpm membedakan jawaban benar dari kedua kelompok tersebut.

Dari item-item yang taraf kesukarannya cukup biasanya dapat diperoleh indeks daya pembeda yang relatif tinggi. Hal ini terjadi karena item-item yang demikian dapat dijawab secara benar oleh sebagian siswa yang tergolong kelompok atas dan sebagian kecil siswa yang tergolong kelompok bawah.

- Mengenai hubungan antara indeks kesukaran denagn indeks daya pembeda suatu item, dikenal indeks daya pembeda ideal (yang dapat diharapkan).

- Yang dimaksud adalah indeks daya pembeda yang setinggi mungkin diperoleh dengan taraf kesukaran (TK) tertentu, dengan catatan bahwa sedapat mungkin prestasi siswa yang tergolong kelompok atas setinggi mungkin atau mendekati besar skor yang dituntut oleh item tersebut

\section{Guru di minta secara langsung} mempraktekkan salah satu teknik analisis butir soal secara kuantitatif

Pada kegiatan ini guru secara berkelompok menggunakan 
laptop dengan bantuan program excel menentukan salah satu mata pelajaran yang hendak di analisis dan mempraktekkannya sesuai dengan materi yang disampaikan untuk mengetahui bagaimana tingkat kesukaran, daya pembeda, omit serta dikstator dari soal tersebut, sehingga dapat di simpulkan apakah soal tersebut layak dipertahankan ataukah harus diperbaiki bahkan dihapus.

\section{Khalayak Sasaran}

Sasaran pelaksanaan kegiatan pengabdian kepada masyarakat adalah Guru SMK di Kecamatan Cileungsi Bogor. Pelaksanaan pegabdian kepada masyarakat dengan judul "Workshop teknik menganalisis butir soal dalam meningkatkan kompetensi guru smk dalam evaluasi pembelajaran sesuai kurikulum 2013 di smk cileungsi bogor" ini dilaksanakan di Ruang Serba Guna SMK Amal Mulia KabupatenBogor dengan narasumber Ati Sumiati, S.Pd, M.Si dan Umi Widyastuti S.E, ME. Workshop ini dihadiri oleh ketua yayasan dan Available at http://journal.unj.ac.id/unj/index.php/jpm kepala SMK Amalmulia serta sekitar 30 guru sebagai peserta.

\section{Metode}

Ceramah, panel, diskusi kelompok dan praktek untuk Menganalisis butir soal. Pada saat menjelaskan dan sharing informasi kepada peserta, pembicara menggunakan metode ceramah dan diskusi. Selanjutnya guru diberikan kesempatan untuk bertanya dan mencoba menganalisis kasus yang diberikan.

Unversitas Negeri Jakarta membiayai pengabdian kepada masyarakat yang dilaksanakan oleh dosen-dosen sebagai bagian dari Tri Darma Perguruan Tinggi.

Satuan Tingkat Pendidikan pada Tingkat SMK di Kecamatan Cileungsi Bogor dengan tujuan untuk meningkatkan kemampuan guru SMK di Kecamatan Cileungsi dalam merancang menyusun dan melaksanakan evaluasi pembelajaran bagi guru dalam mengajar. Di samping itu, melalui peningkatan kemampuan menganalisis soal yang di susunnya diharapkan dapat mendorong kemampuan mereka dalam menyusun soal yang baik dan 
membuat bank soal.

Bagi siswa sebagai in put dan juga out put merupakan salah satu pengguna soal yang telah dianalisis sehingga mempermudah evaluasi pembelajaran dan meningkatkan pencapaian tujuan pembelajaran secara maksimal.

\section{HASIL KEGIATAN}

Pelaksanaan pegabdian kepada masyarakat dengan judul "Workshop teknik menganalisis butir soal dalam meningkatkan kompetensi guru smk dalam evaluasi pembelajaran sesuai kurikulum 2013 di smk cileungsi bogor" ini dilaksanakan di Ruang Serba Guna SMK Amal Mulia KabupatenBogor dengan narasumber Ati Sumiati, S.Pd, M.Si dan Umi Widyastuti S.E, ME .

Kegiatan ini dilaksanakan hari Sabtu, tanggal 13 Mei 2017 dari jam 08.00 WIB sampai dengan jam 12.00 dengan dua sesi yaitu:

\begin{tabular}{|l|l|l|}
\hline No & Kegiatan & Materi \\
\hline 1 & Sesi 1 & Perkenalan tentang konsep analisis butir soal \\
\hline 2 & Sesi II & $\begin{array}{l}\text { Praktek bagaimana langkah-langkah } \\
\text { menganalisis butir soal yang sesuai dengan } \\
\text { mata pelajaran yang di ampu oleh guru }\end{array}$ \\
\hline
\end{tabular}

\section{Sesi Pertama}

Pengetahuan tentang

menganalisis butir soal di sampaikan

oleh Bu Umi Widyastuti dengan

diskusi dan langsung tanya jawab

dengan guru. Sesi pertama ini

menyampaikan materi tentang teknik

analisis secara kualitatif dan

kuantitatif serta bagaimana langkah-

langkahnya.

Available at

http://journal.unj.ac.id/unj/index.php/jpm

\section{Sesi Kedua}

Setelah mendapatkan

pengetahuan mengenai analisis butir soal, maka setiap guru dalam kelompok mencoba menganalisis butir soal salah satu mata pelajaran yang diampu dengan menggunakan teknik analisis secara kuantitatif (tingkat kesukaran, daya pembeda, omot dan distraktor), yang kemudian 
hasilnya didiskusikan kepada yang lainnya.

\section{KESIMPULAN DAN SARAN}

\section{Kesimpulan}

- Pelaksanaan Workshop teknik menganalisis butir soal dalam meningkatkan kompetensi guru smk dalam evaluasi pembelajaran sesuai kurikulum 2013 di SmkAmal Mulia Cileungsi Kab Bogor dapat membantu guru dalam evaluasi atas tes yang akan di gunakan.

- Melalui pelatihan tersebut pun diharapkan dapat menambah pengetahuan guru mengenai pembuatan teknik analisis butir soal baik secara kualitatif maupun kuantitatif.

- Guru dapat merancang soal yang sesuai dengan pencapaian kompetensi yang diinginkan secara efektif.

- Workshop teknik analisis butir soal dapat diharapkan dapat meningkatkan keterampilan guru dalam membuat soal.

\section{Saran}

- Setiap tingkat satuan pendidikan dan guru terus dapat melatih diri dalam teknik menganalisis butir soal yang sesuai dengan pencapaian kompetensi pembelajaran.

- Dapat terwujud kesadaran bagi setiap guru untuk mengembangkan keterampilannya dalam menyusun soal yang baik dan efektif.

- Dapat meningkatkan keterampilannya memilih dan menggunakan soal-soal tersebut pada bank soal.

\section{DAFTAR PUSTAKA}

Arikunto, Suharsimi. 2009. Dasardasar Evaluasi Pendidikan. Jakarta: Bumi Aksara.

Arikunto, Suharsimi dan CepiSafrudin Abdul Jabar. 2004.

EvaluasiProgramPendidikan. Jakarta: BumiAksara.

Azwar, Saifuddin. Fungsi dan Pengembangan Pengukuran Prestasi Belajar. Edisi II. Yogyakarta: Pustaka Pelajar.

Hamalik, Oemar. 2001. Teknik Pengukuran dan Evaluasi Pendidikan. Bandung: Mandar Maju

Isjoni. 2003. Evaluasi Belajar Mengajar. Pekanbaru: Unri Press.

Peraturan Menteri Pendidikan Nasional Republik Indonesia Nomor 23 Tahun 2006 tentang Standar 


\section{Kompetensi Lulusan,} Jakarta, 2006.

UU No 20 Tahun 2003 Tentang Sistem Pendidikan

Nasional,

Peraturan Pemerintah No 32 Tahun

2013 Tentang Standar Nasional Pendidikan

Permendikbud No 54 Tahun 2013 tentang Standar

Kompetensi Lulusan Pendidikan Dasar dan Menengah.

Permendikbud No 64 Tahun 2013 Tentang Standar Isi

Permendikbud No 65 Tahun 2013

Tentang standar proses

Permendikbud No 66 Tahun 2013

Tentang standar penilaian

Permendikbud No 69 Tahun 2013

Kerangka dasar kurikulum

Sekolah

Menengah

Atas/Madrasah Aliyah.

Permendikbud No 81 A Tahun 2013

, Lampiran Implementasi kurikulum pada sekolah dasar/madrasah ibtidaiyah (SD/MI), sekolah menengah

pertama/madrasah

tsanawiyah (SMP/MTs), sekolah menengah atas/madrasah aliyah (SMA/MA), dan sekolah menengah

kejuruan/madrasah aliyah kejuruan (SMK/MAK) dilakukan secara bertahap mulai tahun pelajaran 2013/2014.

Masidjo, Ign. 1995. Penilaian Pencapaian Hasil Belajar Siswa Di Sekolah.

Yogyakarta: Kanisius.

Peraturan Menteri Pendidikan Nasional Republik

Indonesia Nomor 24 Tahun 2006 tentang Pelaksanaan

Standar Isi dan Standar Kompetensi Lulusan sebagaimana telah diubah dengan Peraturan Menteri Pendidikan Nasional Republik Indonesia Nomor 6 Tahun 2007. Jakarta: Direktorat Jenderal Manajemen Pendidikan Dasar dan Menengah.

Purwanto, Ngalim. Prinsip-prinsip dan Teknik Evaluasi Pengajaran. Bandung: PT Rosda Karya, 2007.

Undang-Undang Nomor 20 Tahun 2003 tentang Sistem Pendidikan Nasional, Jakarta: Fokus Media.

Rohani, Ahmad. Pengelolahan Pengajaran. Edisi Revisi. Jakarta: PT. Rineka Cipta

Sudjana, Nana. 2007. Penilaian Hasil Proses Belajar Mengajar. Bandung: Rosda 